\title{
Kreacja mniejszości narodowościowych i problem identyfikacji jednostki - Grenki med Andreja Skubica
}

\author{
Regina Wojtoń \\ Akademia Techniczno-Humanistyczna, Wydziat Humanistyczno-Społecznye, \\ Ul.Willowa 2,PL-43-309 Bielsko-Biała,rwojton@ath.bielsko.pl
}

SCN II/2 [2009], 129-138

Prispevek, katerega tema je način predstavitve narodnih manjšin v romanu Andreja Skubica Grenki med, je poskus identifikacije pravega junaka romana. V času globalizacije se teh problemov loteva tudi leposlovje. Da bi dosegli želeni cilj, si avtorji zamišljajo svet in vanj umeščajo glavne like, ki jih lahko analiziramo z različnih vidikov. Ker imajo literarni liki obravnavanega romana težave z lastno identiteto, ne znajo enoumno opredeliti svoje družbene in narodne pripadnosti.

The main subject of this paper is the presentation of national minorities in Andrej Skubic's novel Grenki med/Bitter Honey, and an attempt to identify the novel's true hero. In times of globalization, fiction deals with these problems as well. In order to achieve their aims, authors imagine a world, placing in it main characters which can be analyzed from various perspectives. Having problems with their own identity, the characters in the novel are unable to determine their social and national affiliations.

Ključne besede: generacija, globalizacija, migracija, roman

Key words: genaration, globalization, migration, novel

Grenki med (Gorzki miód) Andreja Skubica to powieść o cudzoziemcach w Słowenii, cudzoziemcach w Anglii, cudzoziemcach w Szkocji. Głównymi bohaterami są tłumacze oraz lektorzy języka angielskiego, zatrudnieni przez biuro tłumaczeń „Idiom” i Wydział Filozoficzny Uniwersytetu w Lublanie: Brian, Danny, Duane, Jenny i Richard.

Skubic pokazuje antagonizmy na podłożu narodowościowym i kulturowym jako pochodną globalizacji świata. Migracje zarobkowe, konformistyczny pęd 
innych kultur za kulturą angloamerykańską, w Europie natomiast proces integracyjny z jednej strony sprzyjają co prawda poznawaniu innych nacji, z drugiej jednak prowadzą do narastającej ksenofobii oraz deprecjacji mniejszości narodowych, a niekiedy również ,pielęgnowaniu” osobistych, niejako wpisanych w nacjonalny genotyp autostereotypicznych kompleksów, o których Skubic pisze na „masochistyczne życzenie słoweńskiego czytelnika” (Strsoglavec 2005: 93) chociażby po to, aby ów mógł się czegoś niedobrego na swój temat dowiedzieć.

Nic dziwnego, że Brytyjczyków złości słoweńska biurokracja, malkontencka natura obywateli krajów byłego bloku wschodniego. Nie zaskakuje także fakt, iż nie mogą się odnaleźć w labiryntach administracji państwowej oraz publicznej; zresztą podobne zachowania można dostrzec po drugiej stronie - Słoweńcy widzą Anglików i Szkotów inaczej, niż oni sami. Chodzi o klasyfikację cech narodowych czy chociażby przyzwyczajeń nie tyle jako aksjologicznie złych, co po prostu nieakceptowanych z punktu widzenia osobistych przekonań, oraz identyfikowanych jako własności nabytych, naturalnie od innych gorszych nacji:

Duane [...] Sendvič odloži na pult, potem pa odpre kredenco in potegne ven veliko džezvo iz rostfraja. Jenny ga z glavo, naslonjeno na dlani, ki ji počivajo na mizi, mrko opazuje. Zakaj si ne moreva nabaviti spodobnega avtomata za kavo? Zakaj se mora afnati s temi balkanskimi pripomočki? Skrajni čas, da si kupim kakšen nescafé. Jebemti, kako je otročji. Kako fajn se mu zdi, da se lahko dela domačina, jaz pa moram za kazen piti to kavo, ki trga gate. (Skubic 2000: 145-146)

[Duane [...] kładzie kanapkę na blat, potem otwiera kredens i wyjmuje wielką ceramiczną dżezwę. Jenny z głową opartą na dłoni, sennie go obserwuje.

Dlaczego nie możemy kupić przyzwoitego ekspresu do kawy? Dlaczego musi się bawić tymi bałkańskimi zabawkami? Najwyższy czas kupić kawę rozpuszczalną. Ja cię pieprzę, ale jest dziecinny. Wydaje mu się, że jest taki fajny, jeżeli zachowuje się jakby był stąd... A ja muszę, chyba za karę, pić tę kawę, po której ma się wrażenie, że za chwilę wyskoczy się z portek. (tłumaczenie moje - R. W).]

Njej bi pristal kakšen osladen tip, plavolas šminker iz solarija, mogoče Italijan ali Francoz, bodybuilder, ki za zajtrk poje pol šunke in tri jajca [...] ne pa nekakšen razkuštran vegetarijanski Anglež, ki ga ni nič skupaj in ki ne zna velikemu piru nikoli reči ne. [...] Iain je bil res pravi Balkanec. Tako, kot vsi Škoti. (Skubic 2000: 148-149)

[Jej pasowałby jakiś słodki typek, jasnowłosy laluś prosto z solarium, być może Włoch a może Francuz, jakiś paker, który na śniadanie zjada pół szynki i trzy jajka [...] a nie jakiś rozczochrany Anglik - wegetarianin [...], który nigdy nie odmawia sobie dużego piwa. [...] Iain był prawdziwym Bałkańcem. Jak i wszyscy Szkoci. (tłumaczenie moje - R. W.)]

Bohaterowie Skubica niekiedy z góry deprecjonują ,innych”. Począwszy od reprezentowanych przez nich hierarchii wartości i poziomu intelektualnego, na preferencjach towarzysko - seksualnych skończywszy:

Na srečo je razvil svojo teorijo $\mathrm{v}$ drugo smer. Kaj, tebe spolno vznemirjajo samo še Slovanke, je rekel ... Zelo dobro, Charles Atkinson. Toda nazadnje se je Chaz vseeno nekoliko obrnil in sledil mojemu pogledu. Znotraj lokala, tik za oknom, tako, da jih je bilo mogoče dobro videti, je bila večja družba iz hostla ... že precej vesela. Tik pred oknom, 
skoraj naslanjala se je nanj, je stala mlada, suha ameriška receptorka. Chazov pogled se je osredotočil naravnost nanjo. Potem se je znova obrnil proti meni in mi pomežiknil. Tako torej, je rekel, ampak Duane, jebemti boga, ona je Američanka. Kje so tvoji etični zadržki?

Jebiga, Chaz, sem rekel, od kdaj imajo kurci etične zadržke? (Skubic 2000: 114-115)

[Sam sobie wydawałem się trochę głupi. Chaz miał rację. W końcu pomyśli jeszcze, że zostałem biednym, nudnym impotentem. Na szczęście swoją teorię rozwinął w innym kierunku. No i jak... Podniecają cię tylko Słowianki? [...] Bardzo dobrze, Charlesie Atkinsonie... W końcu Chaz, niby nic, trochę obrócił się w moim kierunku i podążył za moim wzrokiem. W środku, tuż za oknem, tak, że można ich było dobrze widzieć, było większe towarzystwo [...] już w odpowiednim nastroju. Tuż obok okna, a właściwie oparta o nie, stała młoda, chuda amerykańska recepcjonistka. Wzrok Chaza skoncentrował się dokładnie na niej. Potem odwrócił się do mnie i mrugnął okiem. - Więc tak... - powiedział - na litość boską, Duane, to jest Amerykanka. Gdzie sa twoje hamulce etyczne? Spadaj, Chaz - powiedziałem - od kiedy kutasy mają hamulce etyczne? (tłum. moje - R. W.)]

Obraz relacji jakie budują bohaterowie Skubica odzwierciedla kondycję społeczną jemu współczesnych, gdzie tworzone więzi międzyludzkie mają karykatuaralną postać, niweczą bowiem zaufanie, którego miejsce ,zajmuje powszechna podejrzliwość. Wszystkie więzy uznaje się za niepewne i niewiarygodne, wszędzie węszy się podstęp i pułapkę, dopóki nie znajdzie się dowód na to, że jest inaczej. [...] Próby nawiązania i zacieśniania więzów zmieniają się w nieskończony ciąg eksperymentów. A jako czysto eksperymentalne przyjęte jedynie „na próbę”, wciąż poddawane próbie i zawsze prowizoryczne [...] międzyludzkie sojusze, zobowiąznia i więzy nie mają zbyt wielkiej szansy, aby okrzepnąć na tyle, by można je było uznać za w pełni wiarygodne. Zrodzone z podejrzliwości rodzą same podejrzenia” (Bauman 2004: 144-145).

Bohaterowie wiodą, „życie ludzkie, odarte z zaufania i przesiąknięte podejrzliwością [padają] łupem sprzeczności i wieloznaczności” (Bauman 2004: 145), z którymi nie umieją sobie poradzić. Ich życie wygląda niczym niepewny bieg znaczony ,kolejnymi rozczarowaniami i frustracjami, i zawsze dociera ono do tego właśnie punktu, z którego chciało się uciec, rozpoczynając podróż w nieznane. Życie w ten sposób przeżywane pozostawia po sobie cały szereg chybionych i poniechanych związków - odpadów wytwarzanych w warunkach globalnego pogranicza, gdzie zaufanie jest znakiem naiwności, pułapką na niezaradnych i łatwowiernych" (Bauman 2004: 146).

W obliczu takiej sytuacji bezpiecznie poczuć się nie sposób. Brak wzajemnego zrozumienia, niechęć do negocjacji pomiędzy przedstawicielami poszczególnych narodowości Skubic niejako sygnalizuje za pomocą nazwy biura tłumaczeń - „Idiom”, w której zatrudnieni są bohaterowie powieści Grenki med. Idiom - ,jako pewien stały zwrot frazeologiczny, występujący w określonym języku i nie dający się przełożyć w sposób dosłowny” (Jaworski 2001: 91), stanowi znaną każdemu uczącemu się języków obcych barierę - wyzwanie, któremu ten albo podejmuje się sprostać albo ignoruje je kosztem lepszej znajomości danego języka. Próba przetłumaczenia pewnej frazy najczęściej 
polega na odnalezieniu możliwie najbliższego ekwiwawelentu na gruncie języka rodzimego, z uwzględnieniem specyfiki obydwu kultur. Ogólnie rzecz ujmując, chodzi o poszukiwanie wspólnego lingwokulturowego mianownika idiomów. Sukcesem będzie zatem, jeżeli nawet nie odnalezienie pełnego odpowiednika, to możliwie głębokie zrozumienie obcej frazy.

I tak, jak napotykane nieznane słowa bądź frazy prowokują do znajdowania ich znaczenia, tak samo ich nosiciele - obcy są niejako pretekstem do zmiany dotychczasowej optyki widzenia siebie, czasem i ich domniemanym zaprzeczeniem. Na zasadzie wyostrzonego kontrastu można zobaczyć więcej, a niekiedy również docenić.

W powieści Skubica na zasadzie przeciwwagi Anglików oraz Szkotów występuje kilku słoweńskich protagonistów; wśród nich najbardziej wyprofilowana jest postać Jany, która poprzez spontaniczne wypowiedzi i przemyślenia znajomych jej cudzoziemców bodajże najgłębiej analizuje swoją tożsamość narodową (Strsoglavec 2005: 98), biorąc pod uwagę także różnice dzielące samych Słoweńców, na przykład tych mieszkających w stolicy i tych, którzy mieszkają na prowincji. Mieszkańcy stolicy Słowenii w przeciwieństwie do prowincjuszy postrzegają siebie jako obywatele Europy, a zatem chętnie i bezkrytycznie naśladują inne „europejskie” wzorce (np. angielskie), co oczywiście z jednej strony ma doprowadzić do osiągnięcia ,europejskiego” ideału, z drugiej wyleczyć owe „słowiańskie” kompleksy. Jana mówi:

Všeč so mi tile podeželani. Čisto nekaj drugega so kot tista ljubljanska evropska kvazismetana. Tudi do tujcev se obnašajo veliko bolj naravno. Niso tako klečeplazni kot Ljubljančani, ki se grejo svetovljane in so Angleži zanje kot nekakšen čuden civilizacijski ideal. Tile kmetje so sproščeni, ker so neobremenjeni. Oni so tukaj doma. Ti si obiskovalec, in kot tak boš tudi postrežen, ne bodo te skušali impresionirati, kako zelo so ti enakovredni. (Skubic 2000: 285)

[Podobają mi się ci prowincjusze. Są zupełnie inni niż ta lublańska europejska quasi - śmietanka. W stosunku do cudzoziemców też zachowują się bardziej naturalnie. Nie schlebiają tak, jak lublanianie, którzy myślą, że są święci, a Anglicy dla nich są jakimś dziwnym ideałem cywilizacyjnym. Ci ze wsi są zrelaksowani, bo nie są ograniczeni. Oni tutaj są w domu. Ty tutaj jesteś gościem i tak też będziesz traktowany. Nie będą starali się wywrzeć na tobie wrażenia, ponieważ mają takie same poczucie własnej wartości. (tłumaczenie moje - R. W.)]

Bohaterowie Skubica to współczesne nomady poszukujące swojego miejsca na ziemi. Swoje nowe domy nie oceniają pod względem kryterium użyteczności materialnej, ale atmosfery danego miasta. Dom jest według nich wszędzie tam, gdzie czują się dobrze. Nie decyduje o tym bynajmniej identyfikacja etniczna, ale związki międzyludzkie, umiejętności przystosowawcze w nowym środowisku, a nie patriotyczny sentymentalizm, reasumując: poczucie niezależności, a nie przynależności. Ich ojczyzna to pewien ,zbieg okoliczności, ziemi i nieba” (tłumaczenie moje; Садловский 2005: 41). To współcześni kosmopolici - poszukiwacze, których domem jest droga albo raczej cały dostępny im świat. Pewną analogią literacką będzie tutaj bohaterka Olgi Tokarczuk, która tak opisuje jej „sposób na życie”: 
Jej domem jest droga, mieszka w podróży. A podróż nie jest linią, która łączy dwa punkty w przestrzeni - to inny wymiar, to stan. Nic w nim nie jest oczywiste, nic nie jest nieprawdopodobne; szlaki są gęste i splątane przenikają się w nieoczekiwanych miejscach. (Tokarczuk 2004: 260)

Przedstawicielem tego pokolenia jest Duane, który nie traktuje siebie jako mieszkańca rodzinnego Newcastle; woli być cudzoziemcem mieszkającym w Lublanie, która to wydaje się być absolutnym przeciwieństwem miasta, z jakiego pochodzi:

Newcastle ... kako out sem v tem času vmes postal tukaj. [...] Tukaj od mene vsi pričakujejo, da se bom počutil, kot se spodobi za nekoga, ki je po nekaj letih prišel domov. Domov? Kakšen dom neki. V vseh teh letih me ni niti enkrat vleklo v Newcastle. Niti enkrat samkrat. Ko je bilo takrat Prage konec, sem prišel domov z eno samo mislijo; kako se čim prej spet pobrati stran. $V$ tem sivem in rjavem in rdečem mestu sem preživel dvaindvajset let, pa se nisem nikoli navijal.

[...] Zakaj naj bi se po vseh teh letih vračal? [...] Ljubezen do mame, navezanost na rodni kraj? Ja, pa kaj še. Odkar se spomnim, sem se počutil zares udobno, resnično domače samo zunaj tega kurčevega Newcastla. Na obisku pri Chazu, ki je študiral v Glasgowu. V Pragi. Na obisku pri Toszki doma v Krakovu. V Ljubljani. [...] Ljubljana mi ni dala nobene druge možnosti, kot da sem to, kar sem. Nobene. Ko pripotuješ v Ljubljano, te že takoj na začetku postavi na pravo mesto; na mesto tujca. S tega mesta se da sicer počasi napredovati, ampak samo toliko, kolikor sam hočeš. V Ljubljani lahko, če hočeš, za vedno ostaneš tujec. Nič lažjega: celo spodbujala te bo pri tem. Ljubljana se diči s takimi, kot sem jaz. Šarmantni tujec z Newcastla. (Skubic 2000: 43-46)

[Newcastle. [...] jak bardzo jestem daleki od tego miejsca. [...] tutaj wszyscy oczekują ode mnie, że będę się czuł jak ktoś, kto po latach wrócił do domu. Do domu? Cóż to za dom? W ciągu tych wszystkich lat, ani razu nie ciągnęło mnie do Newcastle. Ani razu. Kiedy wróciłem z Pragi, myślałem tylko o jednym: jak najszybciej stąd wyjechać. W tym szaroburym i czerwonym mieście przeżyłem dwadzieścia dwa lata, ale nigdy nie czułem się tutaj jak w domu. Nawet nie kibicowałem drużynie piłkarskiej z Newcastle. [...] Do czego niby mam tutaj wracać? [...] Miłość do mamy, przywiązanie do rodzinnego miejsca? Tak... I co jeszcze... Odkąd pamiętam, najlepiej czułem się poza tym pieprzonym Newcastle. U Chaza, który studiował w Glasgow. W Pradze. W domu Toszki w Krakowie. W Lublanie. [...] Lublana nie dała mi żadnego wyboru, poza tym, że tutaj jestem tym, kim jestem. Żadnego. Kiedy przyjedziesz do Lublany, od razu znajdziesz się na właściwym miejscu; na miejscu cudzoziemca. Z tego miejsca da się powoli, bardzo powoli ruszyć do przodu, ale tylko tyle, ile sam chcesz. W Lublanie możesz zostać cudzoziemcem na zawsze. Nic prostszego: to miasto utwierdzi cię w tym przekonaniu. Lublana ozdabia się takimi jak ja. Szarmanckim cudzoziemcem z Newcastle (tłum. moje - R. W.)]

Specyfika powieści Andreja Skubica polega na rozszyfrowaniu języka bohaterów, których wielojęzyczność w pewnym sensie jest „przetłumaczona” W słoweński socjolekt z prowokującą mimetycznością (Zupan-Sosič 2003: 148) języka potocznego poszczególnych postaci. Jana, Duane, Chaz nie stronią od wulgaryzmów, wszechobecnych anglicyzmów, których okcydentalność podkreśla przynależność do ponowoczesnego świata. Ten język „zdaje się odzwierciedlać potrzebę oderwania się członków społeczeństwa od dawnej 
epoki i zaistnienia w nowej rzeczywistości” (Mosiołek - Kłosińska 1999: 38) Ich indywidualizm dodatkowo jest zaznaczony w warstwie graficznej utworu; monologi wewnętrzne zaznaczone są kursywą, mniejszą, kilkupunktową zaledwie czcionką zaś są wyróżnione listy internetowe, co pozwala stwierdzić, iż Gorzki miód nosi znamiona powieści epistolarnej (listy noszą wszystkie cechy tej formy komunikacji, a więc m.in. skrótowość motywowana ekonomizacją języka, potoczność i indywidualne nacechowanie stylu).

Skubic w ten sposób nobilituje Internet, co każe się również zastanowić, nad klasyfikacją tejże powieści, a więc czy należy ona do literatury pięknej czy popularnej (w Polsce podobne zjawisko miało miejsce w momencie wydania tryptyku Janusza Leona Wiśniewskiego noszącego znamienny tytuł Samotność w sieci; Wiśniewski 2001). Ponadto zwraca uwagę na stopniowe zacieranie się granicy pomiędzy kulturą wysoką a kulturą masową, co przekłada się również na kondycję literatury, która zmuszona została do konkurencji z innymi środkami przekazu, a zatem sama musi zadbać o utrzymanie swojej pozycji rynkowej.

Nie chodzi tutaj tylko o zawartość i nawet o sam potencjał informacyjny „stron WWW”, ale bodaj przede wszystkim o Internet, który stanowi obecnie najważniejsze narzędzie komunikacji masowej. Wszak w dobie globalizacji to podstawowe medium, sukcesywnie zastępujące dotychczasowe formy porozumiewania się, takie jak poczta, telefon, telegraf, aż wreszcie osobiste kontakty międzyludzkie. Zygmunt Bauman pisze w Płynnych czasach, o dotkliwej samotności współczesnego człowieka usilnie leczonej za pomocą czyjejkolwiek obecności, choćby i nawet wirtualnej (Bauman 2007: 37). Nie budzą już niczyjego zdziwienia ani wirtualne przyjaźnie czy też związki partnerskie nawiązane bądź za pomocą komunikatorów bądź wyspecjalizowanych portali towarzyskich. Nie zaskakują także społeczności skupione wokół określonego problemu czy pasji omawiających dane zagadnienia na forach internetowych. Dzięki portalom społecznościowym typu „facebook”, którego polskim odpowiednikiem jest ,nasza-klasa”, możliwe jest odnowienie więzi bądź nawiązanie nowych znajomości, gdzie liczba tzw. „znajomych” świadczy w pewnym sensie o byciu osobą towarzyską, cieszącą się zainteresowaniem, a co za tym idzie, wartą zainteresowania innych.

W wirtualnym świecie to jednostka sama kreuje swój wizerunek. Zaczyna od wyboru strony „WWW” - swoistej przestrzeni w której ma życzenie zaistnieć. Tam udostępnia wybrane przez siebie prawdziwe lub fałszywe informacje na swój temat. Za pomocą zamieszczonej fotografii może pokazać innym „forumowiczom”, „,blogowiczom” czy też „randkowiczom” i pozostałym ,znajomym” jak wygląda, czym się zajmuje, ile ma lat, co oczywiście w żadnym wypadku nie oznacza zgodności ze stanem faktycznym; zresztą to, czy dojdzie do ewentualnej konfrontacji internetowych danych z realną rzeczywistością również zależy wyłącznie od niej. Dysproporcja pomiędzy Nadawcą a Odbiorcą, wskazuje na masowy charakter komunikatu internetowego. Nadawca wysyła pewną informację/informacje do anonimowej grupy Odbiorców. Wówczas twórca komunikatu internetowego staje przed koniecznością paradoksalnego pogodzenia perswazyjnej intymności przekazu z powszechnością oddziaływania, niekiedy 
tak jak w komunikacie reklamowym posługując się formułą, zamierzonego kłamstwa" (Bralczyk 2004: 46).

Z drugiej strony Nadawca komunikatu może sobie pozwolić na większą szczerość w stosunku do Odbiorcy/Odbiorców. Retoryka każdego osobistego listu sprzyja otwartości (mam na myśli to, iż jest obojętne, czy jest to list przyniesiony przez posłańca, listonosza, czy otrzymana internetowa wiadomość). Podobnie rzecz się ma w przypadku rozmawiających za pomocą komunikatorów, gdzie fizyczna „nieobecność” uczestników komunikatu paradoksalnie sprzyja szczerości wymiany poglądowej.

Warto się przyjrzeć również przestrzeni wirtualnej i realnej. Otóż w obliczu takiej sytuacji samo określenie ,realna rzeczywistość” nie może już być postrzegane jako wyrażenie pleonastyczne, gdyż obecność przymiotnika ,realna" pozwala uniknąć denotatywnych nieporozumień; stworzenie przestrzeni wirtualnej doprowadziła do swoistego rozszczepienia rzeczywistości właśnie na realną i wirtualną, a co za tym idzie odpowiednio do swoistej schizofrenii realnych osób biorących udział w internetowej komunikacji.

To swoisty sposób autokreacyjnej promocji samego siebie, autolicytacji, niewiele tak naprawdę różniącej się od reklamowania przedmiotu, bowiem „,W świecie, gdzie jednostka pozostawiona jest sama sobie, [...] większość jednostek przekształciła się w narzędzie wzajemnej promocji. [Konsekwencją takiego stanu rzeczy jest - R. W.] nowy indywidualizm, blednięcie ludzkich więzi i więdnięcie solidarności wybite [...] na jednej stronie monety, której rewers przedstawia mgliste kontury „negatywnej globalizacji” (Bauman 2007: 37).

„Samotność w sieci” poszukuje ukojenia wśród innych „samotnych” (Wiśniewski 2001). Niezaspokojone pragnienie zarówno bliskości człowieka jak i jego przynależności do określonej wspólnoty dotyczy również bohaterów Andreja Skubica. Na przykładzie stworzonych przez siebie postaci i ich losów zwraca uwagę na coraz bardziej jako nękające współczesnego człowieka poczucie osamotnienia, strachu niemalże o wszystko oraz chęć poszukiwania miejsca sprzyjającego harmonijnemu rozwojowi osobowości. Tymczasem, współcześni rzuceni w tygiel wielu kultur i nacji, nie zawsze potrafią się w nim odnaleźć i albo demonizują obcych ludzi i miejsca, albo doprowadzają do ich skrajnej idealizacji. Wszędzie obcy, z poczuciem bycia „ludzkimi odpadami, [dla których - R. W.] nie istnieje żadna użyteczna funkcja, którą mogliby pełnić w kraju, do którego przybywają i w którym tymczasowo przebywają, pozbawieni perspektywy asymilacji i wcielenia w nowy społeczny organizm" (Bauman 2007: 60).

To przedstawiciele tzw. pokolenia $\mathrm{X}$ - ludzi urodzonych w latach 70 - tych XX w. Wielkiej Brytanii i innych krajach rozwiniętych, które boleśnie „doświadcza bolączek nieznanych wcześniejszym pokoleniom. Bolączek niekoniecznie większych czy też bardziej dominujących, niosących więcej udręk i upokorzeń, ale z pewnością zasadniczo odmiennych, nowych - rzec by można, bolączek i utrapień, właściwych dla płynnej fazy nowoczesności. Pokolenie to ma również całkiem nowe powody (które częściowo zastąpiły stare, a częściowo 
nawarstwiły się na nich), by nosić w sercu poczucie zagubienia, niepewności..." (Bauman 2004: 22).

Wszechograniający ,lęk jest prawdopodobnie najstraszniejszym z demonów gnieżdżących się w otwartych społeczeństwach naszych czasów. Jednak to niepewność teraźniejszości i przyszłości dają początek najbardziej nieznośnym z naszych lęków. One same z kolei rodzą się z poczucia bezradności: utraciliśmy najwyraźniej wszelką kontrolę, indywidualnie, oddzielnie i kolektywnie - a na domiar złego brakuje narzędzi, które pozwoliłyby nam na odzyskanie kontroli nad siłami kształtującymi nasze wspólne życie, które decydują jednocześnie o zasięgu naszych własnych i ograniczeniach nakładanych na naszą wolność wyboru: kontroli, która wyślizgnęła się albo została brutalnie wyrwana z naszych dłoni. Demona lęku nie da się przegnać, dopóki nie znajdziemy (a dokładniej - nie skonstruujemy) owych narzędzi” (Bauman 2007: 40).

Współcześnie, jak nigdy dotychczas, ludzie świadomi są wrogości cywilizacji. Nowe choroby, mutacje genetyczne, zanieczyszczenie środowiska powodujące zmiany klimatyczne, wymieranie całych ekosystemów - to tylko początek listy zagrożeń, jakie niesie cywilizacyjny postęp. Historia ludzkości to pasmo rozkwitów i upadków wielkich idei oraz cywilizacji. Nigdy to, co przeminęło nie pozostawiało po sobie próżni - na jego miejscu powstawało nowe, niekoniecznie jednak dobre dla wszystkich. Pozycja lidera przynależała silniejszym i trwała dopóty, dopóki na to miejsce nie znaleźli się inni pretendenci.

Okazuje się jednak, iż stały od wielu stuleci wzrost populacji, zwielokrotnienie ilości i tempa przekazywanych informacji pozwala w każdym nowym pokoleniu pomnażać dziedziczone w spadku po przodkach dokonania. W XIX wieku dokonano więcej wynalazków niż przez wszystkie poprzednie tysiąclecia historii, a w wieku XX, każde nowe pokolenie dodawało do ogólnej wiedzy ludzkości tyle, lub nawet więcej, co wszystkie dotychczasowe pokolenia razem wzięte. Jednakże demonizacja, nazwijmy to, dobra, jakie stworzyła ludzkość i które ona nazwała cywilizacją, nie jest motywowana skostniałym konserwartyzmem teraz żyjących. Świat jeszcze nigdy dotąd nie był tak świadomy zagrożeń i jednocześnie tak chętny do podjęcia ogólnoziemskiej - ogólnoludzkiej dyskusji na ich temat.

Nigdy dotąd zjawiska entropijne nie miały miejsca na taką skalę; nigdy też nie było tak nierównych szans. „Nie potrafiąc spowolnić przyprawiającego o zawrót głowy tempa zmian, a co dopiero przewidzieć i kontrolować ich kierunku, koncentrujemy się na rzeczach, na które możemy (albo wierzymy, że możemy) wpływać: próbujemy kalkulować i minimalizować ryzyko, że my sami, bądź nasi w danej chwili najbliżsi, możemy paść ofiarą niezliczonych i niepoliczalnych zagrożeń, które ten mętny świat i jego niepewna przyszłość mogą na nas sprowadzić. Jesteśmy pochłonięci doszukiwaniem się „siedmiu oznak raka" lub pięciu symptomów depresji”, albo przeganianiem widma podwyższonego ciśnienia krwi, wysokiego poziomu cholesterolu, stresu lub otyłości. Innymi słowy, szukamy zastepczych obiektów, na których można by wyładować nadwyżkę egzystencjalnej trwogi” (Bauman 2007: 20-21). 
Przed oczyma czytelnika współczesnej powieści oto jawi się obraz zagubionej jednostki - masy, która wszakże szuka potwierdzenia swojej indywidualności, prawa do bycia ,innym”, ale nie „obcym”, jednostki spragnionej poczucia bezpeczeństwa, jasnych kryteriów oceny rzeczywistości. Problemem okazują się być niezbyt jasno określone role społeczne, a co za tym idzie, błędnie wytyczone wektory społecznego postępowania. To znak naszych czasów, bowiem „... nigdy dotąd jednostka nie była tak pozostawiona sobie samej jak obecnie [...]. Powiedziano mi: Wymyślaj siebie sam, sam wymyślaj swoje własne życie i urządzaj je, jak chcesz zarówno w każdej aktualnej minucie, jak i od początku do końca”. A czy mnie na to stać? Tak całkiem bez pomocy, prób przymiarek, pomyłek i poprawek, a przede wszystkim bez wątpliwości?” (Mrożek 2000: 101). Takie pytania zadają sobie współcześni. Takie same lęki nękają bohaterów Andreja Skubica, nadając ich egzystencji posmak goryczy.

\section{LITERATURA}

Zygmunt BAUMAN, 2004: Życie na przemiat. Tłum. T. Kunz. Kraków: Wydawnictwo Literackie.

--, 2007: Płynne czasy. Życie w epoce niepewności. Przeł. M. Żakowski. Warszawa: Wydawnictwo Sic.

Jerzy BRALCZYK, 2002: Język na sprzedaż. Gdańsk: Wydawnictwo Uniwersytetu Gdańskiego.

Stanisław JAWORSKI, 2001: Podręczny słownik terminów literackich, Kraków: Universitas.

Katarzyna MOSIOŁEK-KŁOSIŃSKA, 1999: Ślady polskich przemian po 1989 roku w stownictwie ogólnym. Polszczyzna w komunikowaniu publicznym. Red. J. Bralczyk, H. Majkowska. Warszawa: Wydawnictwo Uniwersytetu Wrszawskiego.

Sławomir MROŻEK, 2000: Smutek czy depresja, Małe listy. Warszawa: Nor sur Blanc.

Юрій САДЛОВСКИЙ, 2005: Природа таниюю або тактом звідусіль. Рига Львів: P.K.S.

Andrej SKUBIC, 2000: Grenki med, Ljubljana: DZS.

Đurđa STRSOGLAVEC, 2005: Meje moje kulture so meje mojega sveta (Večkulturnost v prozi Polone Glavan in Andreja Skubica). 41. seminar slovenskega jezika, literature in kulture: Večkulturnost v slovenskem jeziku, literaturi in kulturi. Zbornik predavanj. Ljubljana: Filozofska Fakulteta.

Olga TOKARCZUK, 2004: Ostatnie historie. Kraków: Wydawnictwo Literackie.

Janusz Leon WIŚNIEWSKI, 2001: Samotność w sieci: Tryptyk. Wołowiec: Wydawnictwo Czarne, Prószyński. 
Alojzija ZUPAN-SOSIČ, 2003: Zavetje zgodbe. Ljubljana: Literarno-umetniško društvo Literatura.

\section{OBLIKOVANJE NARODNIH MANJŠIN IN PROBLEM IDENTIFIKACIJE POSAMEZNIKA - GRENKI MED ANDREJA SKUBICA}

Prispevek, katerega tema je način predstavitve narodnih manjšin v romanu Andreja Skubica Grenki med, je poskus identifikacije pravega junaka romana. Vprašanje je, ali je to celotno prebivalstvo Anglije, Škotske in Slovenije ali samo njihovi predstavniki. Kako avtor oblikuje glavne like? Ali je res mogoče razlikovati med identiteto posameznika in pojmom narodnosti? Kako avtor predstavlja posamezne nacije in kako se ta projekcija kaže v luči socioloških raziskovanj? Kakšna je definicija narodnosti in identitete posameznika? In končno, kako narodna pripadnost oblikuje posameznika?

V času globalizacije se teh problemov loteva tudi leposlovje. Da bi dosegli želeni cilj, si avtorji zamišljajo svet in vanj umeščajo barvite like, ki jih lahko analiziramo z različnih vidikov. Ker imajo omenjeni literarni liki probleme z lastno identiteto, ne znajo enoumno opredeliti svoje družbene in narodne pripadnosti. Pri tem jim ne pomaga niti globalizirana kultura niti dolgoletne življenjske izkušnje, ki jih dejansko približujejo bolj h kosmopolitizmu kot k nacionalizmu.

Danes ima na posameznikove izkušnje še večji vpliv kot prej komunikacija, predvsem internet, ki ni samo orodje za sporazumevanje, ampak tudi prostor, kjer se do resnice oblikuje ambivalentna virtualna realnost. V njej se človek pokaže, kakor sam želi. Prav ta izbirnost informacije lahko gradi drugačno sliko posameznika, kar pomeni, da ne prenaša samo vseh njegovih želja po izgledu in osebnosti, ampak oddajniku pokaže samo tisto informacijo, ki jo sam želi. V tem primeru se pokaže njegova želena prispodoba, lahko bi rekli »okužena« avtoidentiteta.

Skubičev roman se loteva prav problema nepotešene potrebe po samoopredelitvi. 